\title{
Online Dispute Resolution: een veelbelovend initiatief voor toegang tot het recht?
}

\author{
Mr. E.M. van Gelder*
}

\begin{abstract}
1 Inleiding
Nederland is wereldwijd een van de koplopers in digitalisering; zo had volgens EU-statistieken in 2017 98\% van de Nederlandse huishoudens toegang tot het internet en was er een vrijwel 100\% 'high-speed' internetdekking. Ook nam Nederland in 2017 de tweede plaats in van de 'Digital Economy and Society Index'. ${ }^{1}$ Vaststaat dat digitalisering geleidelijk doorsijpelt in vrijwel alle aspecten van ons dagelijks leven. Het recht is onvermijdelijk ook aan deze verandering onderhevig. Tegen de achtergrond van de huidige problematiek omtrent de toegankelijkheid van de civiele rechtspraak en voornamelijk binnen de 'incasso-industrie' - hoge griffiekosten, lange wachttijden en complexe procedures - is er een toenemende interesse in de unieke mogelijkheden die ICT biedt om geschiloplossing voor burgers meer toegankelijk te maken. Er wordt door organisaties meer en meer geïnvesteerd in innovatie en in het ontwerpen van onlinevoorzieningen die verschillende functies bieden om geschiloplossing meer betaalbaar, snel en simpel te maken. In het licht van toegang tot het recht vormt online dispute resolution (ODR) daarmee een veelbelovend initiatief. ODR kent veel definities, maar in het algemeen wordt onder ODR verstaan het gebruik van ICT als hulpmiddel in het proces van geschiloplossing. ${ }^{2}$ ODR omvat dus ook de implementatie van ICT binnen de gerechten (e-justice), maar wordt doorgaans opgevat als de synergie tussen ICT en buitengerechtelijke geschiloplossing (alternative
\end{abstract}

* Mr. E.M. van Gelder is promovenda aan de Erasmus Universiteit Rotterdam.

Het onderzoek resulterend in dit artikel heeft funding ontvangen van de European Research Council - ERC Consolidator grant agreement no 726032 ('Building EU Civil Justice: Challenges of Procedural Innovations Bridging Access to Justice, www.euciviljustice.eu). Ik dank mijn collega dr. Jos Hoevenaars voor zijn commentaar op een eerdere versie, en mijn studenten Kim van Wensen en Mark Moenser, die beiden hun Masterscriptie Privaatrecht schreven over e-Court, voor de interessante discussies over dit onderwerp.

1. Eurostat, Internet Access and Use Statistics - Households and Individuals (30 January 2017) (ec.europa.eu/eurostat/statistics-explained/index. php/Internet_access_and_use_statistics_-_households_and_individuals); European Commission, Europe's Digital Progress Report 2017 - Use of Internet and ePrivacy (10 May 2017) (ec.europa.eu/digital-single-market/ en/download-scoreboard-reports).

2. P. Cortes, Online Dispute Resolution for consumers in the European Union, Oxon: Routledge 2011, p. 53. dispute resolution, ADR). ${ }^{3}$ Laatstgenoemde definitie wordt in dit artikel gehanteerd.

Ondanks initiële successen stuiten voornamelijk de privaat gefaciliteerde ODR-voorzieningen, en in het bijzonder $e$-Court, recent op steeds meer weerstand. De voornaamste kritiek is dat de procedure gevoerd bij $e$-Court ten koste gaat van een voldoende rechtsbescherming. $e$-Court is een digitaal arbitrage-instituut en beslechtte vooralsnog jaarlijks duizenden incassogeschillen. Binnen de huidige schuldenproblematiek vormde het een hoopgevende toepassing. Bijna anderhalf miljoen huishoudens in Nederland hebben problematische schulden, meer dan 200.000 huishoudens zitten in een schuldtraject, en ruim 249.000 mensen staan bekend als wanbetaler van de zorgpremie. De nood was dus hoog voor een efficiënte manier van inning van schuldvorderingen. ${ }^{4}$

In dit artikel staat de vraag centraal wat de potentie van ODR is voor de toegankelijkheid van het recht. Hierbij wordt e-Court als casestudy gehanteerd. Ten eerste evalueer ik de mogelijkheden en uitdagingen van ODR aan de hand van drie criteria: afwezigheid van financiële drempels, een geringe periode voor partijen in rechtsonzekerheid en een begrijpelijke procedure. Deze drie criteria staan namelijk centraal bij overwegingen rondom de toegang tot het recht en zijn bij uitstek elementen waarop ODR potentieel een positieve invloed kan hebben. Ten tweede wordt de voornaamste kritiek op e-Court geïdentificeerd en geëvalueerd met een focus op rechtsbescherming, en tracht ik in dit artikel hieruit lessen te trekken voor het bredere veld van ODR. Tot slot geef ik enkele mogelijke oplossingen voor de bekritiseerde elementen en mogelijke knelpunten in huidige vormen van ODR.

\section{Huidige knelpunten in de rechtspraak}

Toegang tot het recht vormt het hart van de rechtspraak binnen elke democratie. Art. 6 lid 1 van het Europees Verdrag voor de Rechten van de Mens (EVRM) waarborgt het recht op een eerlijk proces. De fundamentele beginselen van een eer-

3. P. Cortes, The Law of Consumer Redress in an Evolving Digital Market upgrading from Alternative to Online Dispute Resolution, Cambridge: Cambridge University Press 2018, p. 44.

4. Landelijke Organisatie Sociaal Raadslieden, Rechtspraak op bestelling? Stop Commerciële Rechtspraak, Utrecht: Sociaal Werk Nederland 2018, p. 3 . 


\section{Maandblad \\ Vermogensrecht}

lijk proces zijn het recht op een eerlijke en openbare behandeling, hoor en wederhoor, berechting binnen een redelijke termijn en door een onafhankelijk en onpartijdig gerecht dat bij wet is ingesteld, en motivering van de uitspraak. ${ }^{5}$ Op grond van de jurisprudentie van het Europese Hof voor de Rechten van de Mens (EHRM) - zoals geoordeeld in Golder vs. the United Kingdom ${ }^{6}$ - omvat het recht op een eerlijk proces ook het recht op toegang tot een gerecht om een actie te starten.? Deze uitspraak had een sneeuwbaleffect; er volgde een reeks uitspraken die het schadelijke effect van praktische drempels voor de toegankelijkheid van het recht benadrukten. Zo oordeelde het EHRM in de zaak Airey vs. Ireland dat de rechten neergelegd in het EVRM niet 'theoretisch' en 'illustratief moeten zijn, maar 'praktisch' en 'effectief. ${ }^{8}$ De invloed van het EVRM en de jurisprudentie van het EHRM op de civiele procedure van de EU is groot; indicatief is de opname van het recht op een effectieve rechtsgang in art. 47 van het Handvest van de grondrechten van de Europese Unie. Dit artikel waarborgt tevens de mogelijkheid van advies, verdediging, vertegenwoordiging en rechtsbijstand. ${ }^{9}$ Het toepassingsbereik van deze fundamentele beginselen omvat ook buitengerechtelijke vormen van geschiloplossing, hoewel de beginselen een andere relevantie kunnen hebben in de context van ADR. Wat betreft het recht op toegang tot de rechter, heeft deze inderdaad relevantie voor ADR. ${ }^{10}$

Het belang van een toegankelijke rechtsgang is groot. Zonder effectief systeem om de rechten van burgers ook daadwerkelijk te waarborgen, zou het recht immers niet meer zijn dan een dode letter. ${ }^{11}$ Het Jaarverslag 2017 van de Raad voor de rechtspraak stelt: 'De Rechtspraak dreigt achterop te raken terwijl de maatschappij vooruit rent, en kan daardoor aansluiting verliezen met de samenleving. Hierdoor zullen mogelijk nog minder mensen hun weg naar de rechter vinden.' ${ }^{12} \mathrm{Om}$ toegang tot het recht daadwerkelijk te realiseren, moet onder andere de financiële drempel niet dermate hoog zijn dat het burgers praktisch onmogelijk wordt gemaakt hun rechten te handhaven. Op basis van de uitspraak Airey vs. Ireland werd het onvermogen om zich juridisch advies te veroorloven gezien als drempel tot toegang. ${ }^{13}$ Het belang van de voorziening van rechtsbijstand om zo de gelijkheid van partijen te

5. X.E. Kramer, Procedure Matters. Construction and Deconstructivism in European Civil Procedure (inaugural lecture Erasmus School of Law), Den Haag: Eleven International Publishing 2013, p. 13.

6. EHRM 21 februari 1975, NJ 1975/462 (Golder/United Kingdom).

7. EHRM 21 februari 1975, NJ 1975/462 (Golder/United Kingdom).

8. EHRM 9 oktober 1979, NJ 1980/376 (Airey/Ireland).

9. I. Benöhr, EU Consumer Law and Human Rights, New York: Oxford University Press 2013, p. 60.

10. E. Bauw, C.C. de Kluiver, M.A. Simon Thomas \& W. van der Woude, Rechtsstatelijke waarborging van buitengerechtelijke geschiloplossing, Montaigne centrum, voor rechtsstaat en rechtspleging 8, Den Haag: Boom juridisch 2018, p. 45.

11. X.E. Kramer, Procedure Matters. Construction and Deconstructivism in European Civil Procedure (inaugural lecture Erasmus School of Law), Den Haag: Eleven International Publishing 2013.

12. De Rechtspraak, Jaarverslag 2017, p. 7.

13. J. Xucla, Access to justice and the Internet: potential and challenges, Committee on Legal Affairs and Human Rights of the Council of Europe, 2015, p. 4. garanderen werd vervolgens door het EHRM benadrukt, zoals in de zaak Steel and Morris vs. the United Kingdom. ${ }^{14}$ Daarnaast moet de periode van rechtsonzekerheid zo kort mogelijk zijn. Rechtspraak die te lang duurt, schiet zijn doel immers voorbij. Het aanpakken van de enorme lengte van juridische procedures is een prioriteit voor het EHRM nu het in een reeks van zaken dit probleem heeft geïdentificeerd, zoals bijvoorbeeld in de zaken Rumpf vs. Germany ${ }^{15}$ en Glykantzi vs. Greece $^{16}$. De rechtsgang dient, evenals de procedurele regels die daaraan verbonden zijn, tevens duidelijk en begrijpelijk te zijn. ${ }^{17}$

Om deze doelen te behalen is er een continue zoektocht naar oplossingen om toegankelijkheid te verbeteren. In de jaren zeventig was er een wereldwijde 'access to justice'-beweging. Deze beweging bracht onder meer teweeg dat een effectieve toegankelijkheid ook buiten de traditionele rechtspraak kan reiken, en omarmde daarbij alternatieve methodes van geschiloplossing als belangrijk onderdeel van de civiele procedure. ${ }^{18}$ Ook de Nederlandse overheid zet sinds de jaren negentig in op het stimuleren van verschillende vormen van buitengerechtelijke geschiloplossing, zoals mediation en arbitrage. ${ }^{19}$ In vergelijking met andere EU-lidstaten scoort de kwaliteit van deze Nederlandse ADR-systemen hoog. ${ }^{20}$ In deze zoektocht wordt er meer en meer ICT ingezet. ${ }^{21}$ Ook Nederland heeft deze mogelijkheden omarmd. In het kader van het digitaliserings- en moderniseringsprogramma Kwaliteit en Innovatie (KEI) heeft digitalisering, ondanks de recente problemen, ${ }^{22}$ geleidelijk haar intrede gedaan binnen de rechterlijke macht. Tegelijkertijd vindt er in toenemende mate digitalisering plaats binnen $\mathrm{ADR}$.

Toenemende werkdruk binnen de rechtspraak, de hoge mate van acceptatie van digitalisering in het algemeen alsook van ADR in Nederland, vormde een vruchtbare bodem voor het ontstaan van een wijd scala aan buitengerechtelijke onlinevoorzieningen die verschillende juridische diensten bieden. In de maatschappij is er een 'doe-het-zelf-trend' ontstaan, waarbij

14. EHRM 15 mei 2005, 68416/01 (Steel and Morris/United Kingdom).

15. EHRM 2 december 2010, 46344/06 (Rumpf/Germany).

16. EHRM 30 januari 2013, 40150/09 (Glykantzi/Greece).

17. L.M. Coenraad \& P. Ingelse, Afscheid van de klassieke civiele procedure? Vernieuwen + behouden = versterken, in: Afscheid van de klassieke procedure? (Handelingen Nederlandse Juristen-Vereniging), Den Haag: Wolters Kluwer 2017, p. 13-138, m.n. p. 18; F. Bakker, Maatschappelijk effectieve rechtspraak, NJB Blog 2016.

18. M. Cappelletti, Alternative Dispute Resolution Processes within the Framework of the World-wide Access-to Justice Movement, MLR (56) 1993, afl. 3, p. 282-296.

19. Coenraad \& Ingelse 2017, p. 32; zie ook Beleidsbrief Meer wegen naar het Recht, Kamerstukken II 1999/2000, 26352, 19.

20. C. Hodges, I. Benöhr \& N. Creutzfeldt-Banda, Consumer ADR in Europe, Oxford: Hart Publishing 2012, p. 164-165.

21. A.A. Sela, The Effect of Online Technologies on Dispute Resolution System Design: Antecedents, Current Trends and Future Directions, LCLR (21) 2017 , afl. 3, p. 635-637.

22. KEI is momenteel stilgezet, onderzoek wees uit dat de doelen te ambitieus waren, het programma te complex en de verdeling van taken en verantwoordelijkheden onduidelijk; zie E.M. van Gelder \& X.E. Kramer, The Deadlock in the Digitisation of the Dutch Judiciary, EUCP (2018) (sites.unimi.it/EUCivilProcedure/index.php/2018/04/25/the-deadlockin-the-digitisation-of-the-dutch-judiciary/). 
burgers verwikkeld in een (dreigend) conflict steeds vaker eerst zelf 'rondshoppen' op het internet op zoek naar oplossingen; dit geldt ook voor wanneer zij verwikkeld zijn in juridische conflicten. ${ }^{23}$ Zulke juridische diensten betreffen inter alia het online verlenen van juridische informatie, juridisch advies (rechtshulp) en het bieden van de mogelijkheid tot het starten ofwel voeren van een procedure. Een van de bekendste voorbeelden is 'Rechtwijzer', een digitale applicatie die burgers verwikkeld in relationele geschillen online juridische informatie verschaft en een diagnose stelt van het probleem. ${ }^{24} \mathrm{Op}$ basis van online door partijen ingevulde vragenlijsten, stelt Rechtwijzer een Stappenplan op van de juridische mogelijkheden en reikt zij partijen concrete hulpmiddelen aan zoals een onlinerekentool voor kinderalimentatie. Doordat deze online juridische diensten in een vroeg stadium van een (potentieel) geschil online informatie verschaffen, wordt zo het eventuele juridische probleem eerder geïdentificeerd waardoor escalatie kan worden voorkomen en daardoor eveneens gerelateerde kosten voor de inschakeling van juridische hulp achterwege blijven.

\section{ICT als redder in nood? e-Court als casestudy}

In het licht van kostenbesparing en tijdwinst biedt ODR verschillende kansen en toegevoegde waarde tegenover traditionele rechtspraak. Aan traditionele rechtspraak zijn inherent kosten verbonden zoals griffierechten, eventuele kosten voor een advocaat en reiskosten. Bij ODR wordt door geautomatiseerde voorzieningen het geschil gecentraliseerd, ongeacht geografische afstanden tussen partijen. Het kan partijen aanzienlijke winst opleveren nu zij geen lange afstanden hoeven te bereizen, en geen feitelijke ontmoeting hoeven te plannen. Afhankelijk van de aard van het geschil behoeven partijen verwikkeld in ODR niet altijd juridisch advies en/of juridische vertegenwoordiging. Dit impliceert uiteraard niet dat partijen verwikkeld in een ODR-procedure geen juridische diensten mogen eisen. ${ }^{25}$ Casemanagementsoftware stelt partijen binnen een ODR-procedure tevens in staat online (delen van) het proces te voeren, zoals onlinecommunicatie, diagnose van het geschil, het indienen van documenten en het inzien van de uitkomst van het geschil vanuit elke plaats en op elke tijd. Partijen krijgen zo zelf meer controle over het proces. In vergelijking met de traditionele rechtsgang, waarbij hiervoor vaak menselijk handelen is vereist, bespaart het tijd en geld. Het ODRproces kan tevens asynchroon plaatsvinden; partijen kunnen dus deelnemen aan de procedure wanneer het hun schikt. Dit voordeel treft vooral partijen verwikkeld in grensoverschrijdende geschillen, zeker wanneer zij in landen met verschillende tijdzones gesitueerd zijn. Het merendeel van de onlinevoorzieningen verleent de juridische informatie kosteloos.

Binnen de Rechtspraak is vooral in het kader van de huidige 'schuldenproblematiek' de nood voor een toegankelijke en

23. J.H. Verdonschot, De technologie van toegang tot het recht, JV (40) 2014, afl. 1, p. 77.

24. Rechtwijzer is een gezamenlijk initiatief van de Raad voor Rechtsbijstand, de Universiteit van Tilburg en HILL en is sinds 2007 van kracht (rechtwijzer.nl/).

25. Xucla 2015, p. 9. efficiënte incassoprocedure hoog. Een van de bekendste voorbeelden van een ODR-voorziening die hiervoor een oplossing poogt te bieden is e-Court. e-Court is een privaat initiatief en biedt op grond van art. 1020 e.v. van het Wetboek van Burgerlijke Rechtsvordering (Rv) digitale arbitrage aan. Op 1 januari 2015 trad de Wet modernisering arbitragerecht in werking. Hierbij werd art. $1072 \mathrm{~b} \mathrm{Rv}$ toegevoegd, dat beoogt in een wettelijke grondslag te voorzien voor het gebruik van elektronische middelen in het arbitrageproces en daarmee aansluiting te vinden bij de steeds snellere ontwikkeling in de praktijk van digitale arbitrage. Naast de oproeping van gedaagde en een eventuele zitting, geschiedt de e-Court-procedure volledig online. ${ }^{26}$ Deze procedure komt doorgaans tot stand doordat in de algemene voorwaarden van de contracten e-Court als arbitragebeding is opgenomen. $\mathrm{Nu}$ de rechtsverhoudingen van partijen bij e-Court meestal consument-bedrijf betreffen, gelden de strikte regels van consumentenbescherming. $Z_{o}$ is de opname van een arbitragebeding in de algemene voorwaarden toegestaan, mits de consument een maand bedenktijd wordt gegund om alsnog te kiezen voor de overheidsrechtspraak (art. 6:236n BW). Instemming met arbitrage betekent niet dat er afstand kan worden gedaan van het recht op een eerlijk proces zoals neergelegd in art. 6 EVRM, zodat de overige - daarin opgenomen - fundamentele beginselen ook in acht moeten worden genomen bij arbitrageprocedures. ${ }^{27}$ De procedure gevoerd bij e-Court dient dus onpartijdige en onafhankelijke arbiters te waarborgen, alsook een gelijke behandeling van partijen, het beginsel van hoor en wederhoor (art. 1036 lid 2 Rv) en motivering van het vonnis (art. 1057 lid 4 sub e Rv). In haar procesreglement ${ }^{28}$ zijn deze fundamentele beginselen neergelegd; zo wordt de onafhankelijkheid en onpartijdigheid van de arbiters gewaarborgd (art. 6 lid 4) evenals twee schriftelijke rondes van hoor en wederhoor (art. 9), evenals de motivering van het vonnis (art. 12 lid 4 sub f). De naleving van een arbitraal vonnis kan worden afgedwongen met een exequatur, dat kan worden verleend door de voorzieningenrechter van de rechtbank (art. $1062 \mathrm{Rv}){ }^{29}$

e-Court stuurt partijen inlogcodes via e-mail, waarmee zij inloggen in het elektronische procesdossier. Binnen deze onlineomgeving vindt de communicatie - zoals het voeren van verweer - plaats, kunnen gegevens en documenten worden geüpload en worden door e-Court automatisch gegenereerde e-mails gestuurd met diverse informatie zoals waarschuwingen voor de afloop van termijnen, het dossier kan continu worden

26. Art. 3 lid 2 Procesreglement e-Court; op grond van art. 11 Procesreglement e-Court 2017 kan een zitting worden gelast, op eigen initiatief van het scheidsgerecht of op eenparig schriftelijk verzoek van partijen, welke plaatsvindt op een fysieke locatie, waarbij partijen het recht hebben deze zaak bij te wonen via digitale communicatiemiddelen. Een gedaagde die echter op geen enkele manier toegang heeft tot het internet mag stukken per post sturen, hierbij worden echter wel de normale tijdslijnen van de procedure gehandhaafd.

27. M.W. Knigge \& P.L.F. Ribbers, Arbitrage, afstand van recht en artikel 6 EVRM, TvA 2017, afl. 2, p. 35-43, m.n. p. 37.

28. Procesreglement e-Court 2017 (www.e-court.nl/wp-content/uploads/ 2017/12/Procesreglement-e-Court-2017_20171222.pdf).

29. Bauw e.a. 2018 , p. 53. 


\section{Maandblad \\ Vermogensrecht}

geraadpleegd door partijen. ${ }^{30}$ Het levert doorgaans kostenbesparing op, zie Tabel 1.

\section{Tabel 1 Vergelijking kosten e-Court en Kantonrechter, tarieven $2018 .{ }^{31}$}

\begin{tabular}{l|l|l|l|}
\hline Hoogte vordering & $\begin{array}{l}\text { e-Court fee } \\
\text { (excl. btw) }\end{array}$ & $\begin{array}{l}\text { Griffierecht } \\
\text { Kanton } \\
\text { niet- } \\
\text { natuurlijke } \\
\text { personen }\end{array}$ & $\begin{array}{l}\text { Griffierecht } \\
\text { Kanton } \\
\text { natuurlijke } \\
\text { personen }\end{array}$ \\
\hline$<€ 500$ & $€ 85$ & $€ 119$ & $€ 79$ \\
\hline$€ 500-€ 750$ & $€ 85$ & $€ 476$ & $€ 226$ \\
\hline$€ 750-€ 5.000$ & $€ 85$ & $€ 476$ & $€ 226$ \\
\hline$€ 5.000-€ 12.500$ & n.v.t & $€ 476$ & $€ 226$ \\
\hline$>€ 12.500$ & n.v.t & $€ 952$ & $€ 476$ \\
\hline
\end{tabular}

Voor vorderingen onder de $€ 500$ is de kantonrechter goedkoper, nu een regulier vonnis direct een executoriale titel oplevert; voor een arbitraal vonnis is immers eerst nog een exequatur - met de daarbij komende kosten - vereist. Voor hogere vorderingen is $e$-Court goedkoper. Incassozaken verlopen volgens de dagvaardingsprocedure. ${ }^{32}$ De doorlooptijd bij een verstekprocedure - een procedure waar de schuldenaar niet verschijnt - kan feitelijk sneller bij de kantonrechter worden beslecht dan bij $e$-Court, indien gekozen wordt voor een dagvaardingstermijn van een of twee weken. ${ }^{33}$ In de praktijk is de dagvaardingstermijn echter doorgaans langer; onderzoek uit 2012 van Kramer e.a. wijst uit dat de gemiddelde dagvaardingstermijn destijds 22 dagen bedroeg. ${ }^{34}$ Hetzelfde onderzoek wijst weliswaar uit dat na gemiddeld 26 dagen een verstekvonnis kan worden verkregen, ${ }^{35}$ maar uit het Jaarverslag van de Raad voor de rechtspraak 2017 blijkt dat de gemiddelde duur in weken bij kantonzaken zes weken bedraagt. ${ }^{36}$ $e$-Court garandeert binnen acht weken een vonnis. ${ }^{37}$ Een verklaring voor deze langere termijn bij $e$-Court kan de wettelijk verplichte wachttijd van $e$-Court zijn, namelijk de maandtermijn die e-Court de gedaagde ex art. 6:236n BW moet geven om alsnog te kunnen kiezen voor de gewone rechter, in plaats

30. Art. 2 lid 1 en 3, art. 3 lid 4, art. 4 Procesreglement e-Court 2017, communicatie geschiedt uitsluitend via het dossier, tenzij anders bepaald.

31. Griffierecht Kanton Tarieven 2018, zie www.rechtspraak.nl/Uw-Situatie/ Onderwerpen/Kosten-rechtszaak/Griffierecht/paginas/griffierechtkanton.aspx.

32. Art. 78 lid 1 Rv.

33. De dagvaardingstermijn is ten minste een week, art. $114 \mathrm{Rv}$.

34. Dit gemiddelde is gebaseerd op een steekproef van 299 zaken, zie X.E. Kramer, M.L. Tuil \& I. Tillema, Verkrijging van een executoriale titel in incassozaken, WODC 2012, p. 48.

35. Dit gemiddelde is gebaseerd op een steekproef van 299 zaken, zie Kramer, Tuil \& Tillema 2012, p. 85.

36. De Rechtspraak 2017, p. 31.

37. e-Court, Persbericht, 19 januari 2018, p. 4. van voor $e$-Court, als de arbitrage via een beding in de algemene voorwaarden is opgelegd. ${ }^{38} \mathrm{Als} e$-Court op een andere wijze wordt overeengekomen dan middels het opnemen in de algemene voorwaarden, is de wachttijd immers niet vereist.

Het merendeel van de onlinevoorzieningen past de geleverde informatie toe op de specifieke situatie van partijen, formuleert de informatie op een begrijpelijke wijze en maakt partijen wegwijs in de verscheidene juridische opties die zij hebben. e-Court wijst een administrateur aan die het procesverloop digitaal organiseert. ${ }^{39}$ Indien partijen na de gegeven informatie nog uitleg behoeven over de procedure kunnen zij de procesbewaking van $e$-Court mailen. ${ }^{40}$

Naast kansen omvat ODR ook uitdagingen voor de efficiëntie van geschiloplossing. Wanneer partijen geen beschikking hebben over geschikte apparatuur of geen toegang hebben tot een netwerk voor internetgebruik kan ODR juist meer kosten met zich meebrengen. Daar Nederland een van de koplopers is in digitalisering, zullen deze kosten naar alle waarschijnlijkheid echter zeer zelden een drempel vormen. Het proces kan voorts vertraagd worden door technische storingen die inherent verbonden zijn aan geautomatiseerde systemen. Een uitdaging voor complexiteit is de digitale ongeletterdheid onder een groep burgers die weinig of geen ervaring hebben met toegang tot en het gebruik van internet. Voor deze groep vormt automatisering juist een extra drempel voor toegang tot het recht. ${ }^{41}$ De organisatie Sociaal Raadslieden ${ }^{42}$ uit ook zijn zorgen over $e$-Court, nu zij dagelijks burgers spreken die niet weten wat $e$-Court is, waarbij het voornamelijk burgers betreft van wie het vermogen om digitaal te handelen gebrekkig is. ${ }^{43}$ e-Court geeft wel uitleg over processtappen en de procesbewaking biedt hulp indien partijen vragen hebben, ${ }^{44}$ maar nu technologie meer geavanceerd wordt en kunstmatige intelligentie (KI) snel in opkomst is, bestaat het risico dat de groep met een gebrekkig vermogen tot digitaal handelen groter wordt. ${ }^{45}$ Voornamelijk de complexiteit van ICT vormt dus een uitdaging voor de toegankelijkheid van ODR, maar de vele voordelen die het biedt om geschiloplossing sneller, goedkoper en simpeler te maken geeft de kracht van ODR aan.

\section{E-Court: identificatie en evaluatie van kritiek}

Alhoewel bovengenoemde informatie uitwijst dat ODR potentieel veel voordelen kan bieden om de eerdergenoemde

38. Art. 6:236n BW.

39. Art. 1 lid 3 Procesreglement e-Court 2017.

40. Art. 3 lid 5 Procesreglement e-Court 2017.

41. E. Katsh \& O. Rabinovich-Einy, Digital Justice: Technology and the Internet of Disputes, Oxford: Oxford University Press 2017, p. 39.

42. Sociaal Raadslieden zijn sociaaljuridische dienstverleners die kosteloos hun diensten aanbieden op gebieden zoals sociale zekerheid, belastingen en huisvesting.

43. Landelijke Organisatie Sociaal Raadslieden, Rechtspraak op bestelling?! Stop Commerciële Rechtspraak, Utrecht: Sociaal Werk Nederland 2018, p. 5.

44. Art. 3 lid 5 Procesreglement e-Court 2017.

45. X.E. Kramer, E. Themeli \& E.M. van Gelder, Digitalization at Full Speed: Innovating Justice in the Netherlands, in: M. Weller \& M. Wendland (red.), Digital Single Market: Bausteine eines Rechts in der Digitalen Welt, Tübingen: Mohr Siebeck, te publiceren in 2018. 
drempels voor specifiek de toegang tot het recht te reduceren en $e$-Court initieel ook een groot succes liet zien, ${ }^{46}$ stuiten deze privaat gefaciliteerde ODR-voorzieningen op steeds meer kritiek. Het is indicatief dat $e$-Court sinds begin dit jaar niet meer in functie is nu kantongerechten geen exequatur meer verlenen voor de arbitrale vonnissen van e-Court. De aanleiding hiervoor was een artikel in de Groene Amsterdammer. ${ }^{47} \mathrm{De}$ kritiek richt zich voornamelijk op zorgen omtrent onvoldoende rechtsbescherming van de gedaagde consumenten binnen de procedure van $e$-Court.

De kritiek wordt in drie fases achtereenvolgens besproken: de overeenkomst tot arbitrage, de uitvoering van de procedure door $e$-Court en de rechterlijke toetsing van de vonnissen van e-Court.

\subsection{De overeenkomst tot arbitrage}

e-Court biedt digitale arbitrage aan. Voor arbitrage geldt dat er tussen partijen een rechtsgeldige arbitrageovereenkomst dient te bestaan. ${ }^{48}$ Het is mogelijk om een arbitragebeding op te nemen in de algemene voorwaarden; het beding voor $e$-Court wordt doorgaans opgenomen in de algemene voorwaarden van de overeenkomst tussen partijen die doorgaans consument en bedrijf betreffen. De plaatsing van een arbitraal beding in de algemene voorwaarden is opgenomen in de lijst voor oneerlijke bedingen consumentenbescherming (art. 6:236n BW), op grond waarvan consumenten ten minste een maand de tijd wordt gegund om alsnog te kiezen voor de rechter indien zij gedaagd worden voor arbitrage. Hoewel e-Court deze termijn waarborgt in zijn Procesreglement (art. 5), worden in de media zorgen geuit of deze termijn in de praktijk wel wordt gehandhaafd. Tevens richt de zorg zich op de vraag of de consument wel (voldoende) op de hoogte is gebracht van het recht om alsnog voor de rechter te kiezen - daar consumenten de algemene voorwaarden doorgaans niet raadplegen - en dus in staat zal zijn om een afgewogen keuze te maken tussen arbitrage en overheidsrechtspraak. ${ }^{49}$ Niemand kan immers tegen zijn wil de toegang tot de rechter worden ontnomen, aldus is bepaald in art. 17 Grondwet en art. 6 EVRM. ${ }^{50}$ Het overgrote deel van de partijen die hun zaak aanbrengen bij e-Court zijn zorgverzekeraars. Zo had begin $201894 \%$ van de zorgverzekeraars een contract met $e$-Court. Cliënten van zorgverzekeraars hebben ook de optie om hun geschil voor te leggen aan de Stichting Klachten en Geschillen Zorgverzekeraars (SKGZ). ${ }^{51}$ Alleen schuldeisers zijn bevoegd een zaak aanhangig te maken bij $e$-Court; schuldenaars zijn daarvan uitgesloten. De vraag

46. Zo behandelde e-Court meer geschillen dan alle andere geschillencommissies bij elkaar en werd in meer dan 8 miljoen rechtsverhoudingen opgenomen zie: A. Jongbloed, $e$-Court; een miskend initiatief om de kosten voor procederende burgers acceptabel te houden, RM Themis 2014, afl. 3, p. 111.

47. K. Kuijpers, T. Muntz \& T. Staal, Vonnis te Koop, De Groene Amsterdammer 2018, afl. 3 .

48. Art. $1020 \mathrm{Rv}$.

49. Kuijpers, Muntz \& Staal 2018.

50. E-Court en 'robotrechtspraak': efficiëntie ten koste van rechtsbescherming, www.sdu.nl/blog/e-court-en-robotrechtspraak-efficientie-ten-kostevan-rechtsbescherming.html.

51. Kamerstukken II 2017/18, 29279, 423, p. 2. rijst daarmee of er wel sprake is van gemeenschappelijke instemming.

\subsection{Uitvoering van de procedure door e-Court}

Aangezien arbitrage een civiele procedure is als bedoeld in art. 6 EVRM dienen arbiters een zaak onafhankelijk en onpartijdig te beslechten, openbare behandeling, controleerbaarheid, hoor en wederhoor toe te passen evenals het vonnis te motiveren. ${ }^{52}$ Op grond van art. 6 lid 4 Procesreglement en $e$ Court's Gedragscode ${ }^{53}$ verplicht $e$-Court de arbiters de zaak onafhankelijk, onpartijdig en naar beste weten uit te voeren. De kritiek richt zich op het anoniem blijven van de arbiters evenals het niet openbaar maken van de arbitrale vonnissen, waardoor op het vlak van de vereiste onafhankelijkheid van arbiters alsmede (de motivering en openbaarheid van) de vonnissen geen controle kan plaatsvinden. -Court wordt zodanig bestempeld als 'black box': er rolt een arbitraal vonnis uit, maar partijen weten niet hoe dit vonnis tot stand is gekomen. Als reactie op de kritiek meldde $e$-Court de intentie hierin verandering te brengen door de lijst met arbiters evenals de vonnissen te publiceren. Vertrouwelijkheid (en de daarmee samenhangende geheimhoudingsplicht) worden als een vast beginsel en kenmerk van het ongeschreven Nederlands arbitragerecht beschouwd. ${ }^{54}$ De vertrouwelijkheid is niet wettelijk verankerd. ${ }^{55}$ Gelet op de aard van de rechtsverhouding van $e$ Court, namelijk consument en bedrijf, die doorgaans ongelijkwaardige partijen betreft, is het echter ondanks het beginsel van vertrouwelijkheid aan te raden om de handelswijze transparant te houden. e-Court stelt, bovenop de vereisten zoals neergelegd in art. $1023 \mathrm{Rv}$, extra kwaliteitseisen aan de arbiters. Zo dienen zij minstens vijftien jaar relevante werkervaring te hebben, evenals een universitaire opleiding. ${ }^{56}$ Deze kwaliteitseisen waarborgen dus ook een bepaalde extra expertise en deskundigheid binnen geschilbeslechting van e-Court. Zorgen omtrent onafhankelijkheid worden verder gewekt doordat e-Court financieel afhankelijk is van bedrijven voor het aanbrengen van zaken, wat leidt tot het risico op belangenverstrengeling.

Een arbitraal vonnis kan ten uitvoer worden gelegd indien de rechter daartoe een executoriale titel verleent. ${ }^{57}$ Tenuitvoerlegging van het vonnis kan worden geweigerd onder meer indien het vonnis of de wijze waarop het vonnis tot stand kwam in strijd is met de openbare orde. ${ }^{58}$ De rechter toetst deze gronden echter slechts marginaal. ${ }^{59} \mathrm{Nu}$ er veel onbekendheid is over de handelswijze van e-Court, rijst de vraag of een

52. Art. 6 EVRM en art. 47 Handvest.

53. Gedragscode Geschilbeslechters 2010, www.e-court.nl/wp-content/ uploads/2017/06/Gedragscode-Arbiters-2017-05-29.pdf.

54. M.A.B. Chao-Duivis, J.M. Hebly \& E.J. Blom (red.), Van het gebaande pad, Stichting Instituut voor Bouwrecht 2016, p. 79.

55. L.C.M. Berger \& E.H. Janssen, De voor- en nadelen van arbitrage, Bb 2017, afl. 10, p. 1.

56. Op grond van art. $1023 \mathrm{Rv}$ kan immers een ieder handelingsbekwame, natuurlijke persoon tot arbiter worden benoemd. Over e-Court: www.e-court.nl/over-ons/.

57. Art. 1062 lid $1 \mathrm{Rv}$.

58. Art. 1065 lid 1 sub e Rv.

59. Art. 1063 lid 2 Rv. 


\section{Maandblad \\ Vermogensrecht}

dergelijke marginale toetsing bij digitale arbitrale vonnissen volstaat.

\section{Conclusie: Na regen komt zonneschijn? De onvermijdelijke rol van digitalisering in geschilbeslechting}

De private markt van ODR groeit en waakzaamheid is vereist. Met e-Court als relevante casestudy kan worden aangetoond dat de potentie van ODR doorgaans de snellere, goedkopere en simpelere wijze van geschilbeslechting is, mogelijk gemaakt door het werken met geautomatiseerde systemen. Tegen de achtergrond van de huidige schuldenproblematiek en de werkdruk binnen de rechtspraak die een voldoende snelle afwikkeling hiervan niet kon garanderen, bood e-Court een veelbelovende toepassing. De voornaamste les uit de kritiek is de nood en eis om ODR-voorzieningen, voornamelijk de private initiatieven, te voorzien van voldoende controle op rechtswaarborgen die het recht op een eerlijk proces garanderen. De efficiëntie van ODR mag dus niet ten koste gaan van rechtsbescherming. Als mogelijke oplossing voor de knelpunten wordt genoemd het invoeren van kwaliteitsstandaarden die toezien op de aanbieders van ODR-voorzieningen, evenals de aanwezigheid en naleving van fundamentele waarborgen van het recht op een eerlijk proces binnen de dienstverlening die zij bieden. Op EU-niveau wordt hier al langere tijd aan gewerkt. Waar het voorheen voornamelijk soft law-instrumenten waren (zoals de EU Aanbevelingen van $1998^{60}$ en 2001 over alternatieve wijze van geschilbeslechting ${ }^{61}$ ), zijn de bevoegdheden van de EU om zich in de civiele procedure te mengen met het Verdrag van Lissabon (2009) aanzienlijk vergroot. Met twee recente initiatieven, de Consumenten ADR-richtlijn 2013/11 en de ODR-verordening 524/2013, poogt de EU bekendheid van en toegang tot ADR/ODR te vergroten en de kwaliteit daarvan te verbeteren. Dit geschiedt door middel van het verlenen van accreditaties aan ADR-aanbieders wanneer zij aan bepaalde kwaliteitsstandaarden voldoen. Deze standaarden verplichten ADR-entiteiten om te beschikken over de juiste expertise, onafhankelijk, onpartijdig en transparant te zijn. Ook dienen hun procedures naar behoren te zijn, evenals effectief en eerlijk, en te voldoen aan de principes van vrijheid en wettigheid. ${ }^{62}$ De ODR-verordening verbindt deze ADRentiteiten met elkaar door middel van een onlineplatform. ${ }^{63}$ Wereldwijd bestaan er ook diverse onlinereputatiesystemen, zoals binnen e-commerce-platforms als e-Bay en Amazon. ${ }^{64}$ De inmenging in het reguleren van ODR moet niet zo ver

60. Commission Recommendation 98/257/EC on the Principles Applicable to the Bodies Responsible for Out-of-Court Settlement of Consumer Disputes, [1998] OJ L 155/31.

61. Commission Recommendation 2001/310/EC on the Principles for Outof Court Bodies involved in the Consensual Resolution of Consumer Disputes, [2001] OJ L 109, p. 56-61.

62. A.B. Biard, Monitoring Consumer ADR in the EU - a Critical Perspective, ERPL 2018, afl. 2, p. 171-196, m.n. p. 173.

63. E.M. van Gelder \& A.B. Biard, The Online Resolution Platform after one Year of Operation: A Work in Progress with Promising Potential, TvC 2018, afl. 2, p. 77-82.

64. R. Susskind, Tomorrow's Lawyers: An Introduction to Your Future, Oxford: Oxford University Press 2017, p. 99 gaan dat het informele karakter en de samenhangende efficiëntie ervan in het geding worden gebracht. ${ }^{65}$ De uitdaging is het vinden van balans.
65. Bauw e.a. 2018 , p. 51. 